\title{
Counseling Services on Management of Students' Discipline in Secondary Schools in Keren Sub-Zone, Anseba Region, Eritrea
}

\author{
Ghebrehiwet Eyasu Andegiorgis
}

\begin{abstract}
The purpose of the study was to assess counseling services on management of students discipline in secondary schools in Keren Sub-Zone, Anseba Region, Eritrea. The research was anchored on Social Learning Theory of Albert Bandura. The study used convergent parallel mixed method research design. Questionnaires and interview guide were used to collect data. A sample of 306 students, 20 teachers, 5 head masters, 5 teacher counselors were used for this study. Systematic sampling, simple random and purposive sampling were used to select schools and the participants. The validity and reliability of the instruments was guaranteed by piloting and Cronbach Alpha technique. Data gathered through questionnaires was processed using descriptive statistical techniques involving frequencies, percentages and means. Results were then presented using tables, pie charts and bar graphs. Data gathered through interview guides was analyzed and presented using quotes, themes and narrative descriptions. The findings of the study show that counseling was minimally used to manage student discipline in secondary schools in Keren subzone. Majority of students, $57.6 \%$ and teachers, $75 \%$ reported that their schools did not have counselling service.
\end{abstract}

Keywords: Counseling services, Students Discipline, students, Counselor, Teacher, head teachers DOI: $10.7176 / \mathrm{JEP} / 10-22-02$

Publication date: August $31^{\text {st }} 2019$

\subsection{Introduction}

Counseling services are crucial in management of discipline in schools (Kimotho, Njoka, and Gitumu, 2017). Implementing of counseling program in schools plays an important role in shaping students' discipline. Schools cannot function well without the exercise of discipline. Students in schools need to be fully guided regarding discipline and attitudes that lead to success in life (Vann, 2013).

Discipline in schools is one of the most pressing issues in the education sector in the world today. Like any other organization, every school requires discipline, for no group of people can work together successfully without establishing standards of good behavior, respect and a desirable system of values that lead each person in the group to develop self-control and self-direction (Luti-Mallei and Komo, 2016).

As reported by Kajunju (2015) the rapid expansion of student enrolment in most African countries since the attainment of political independence, coupled with inadequate resources to cope with the ever increasing demand for educational provision, had made school management a much more complex and difficult enterprise than a few decades ago. Due to the complex nature of school management, counseling services were introduced to assist in managing discipline across Africa.

Schaefer and Ginsberg (2015) in a study conducted in United States of America, reported that counseling services have a proven effect in managing students' discipline. Students who participated in counseling programs had significantly less inappropriate behavior and more positive attitude towards school than those who did not participate in the program.

A study carried out in Bangladesh by Hassain and Faisal (2016) found out that the standards of discipline were declining in Bangladeshi high schools because of lack of formal program for counseling. The study found out that some sort of counseling service is provided to students but those are not planned, organized and holistic. Further, the study revealed that more female students participate in the service provided compared to their male counter parts. One of the major setbacks in Bangladeshi schools is that many schools did not have any trained personal, solely responsible for such services.

A study conducted in Mauritius by Louis, (2018) found out that learners indiscipline cases has become a daily occurrence in secondary schools and the problem has crippled the learning and teaching process in schools. Based on the findings the following are the indiscipline cases witnessed: lack of interest in education, sexual misconduct or inappropriate sexual behavior, students do not do their homework, and do not respect their educators or take orders. The study also found out that there was lack of proper counseling services, lack of counseling resources and lack of well trained counselors in the schools. As the result counseling services in schools were not contributing as expected to curb student indiscipline in Mauritius.

Ajowi and Simatwa (2016) findings show that guidance and counseling was minimally used to promote student discipline in secondary schools in Kisumu District, Kenya. Punishments especially corporal punishment was widely used to solve disciplinary cases in all schools. It was however; found that there were no policy guidelines from the Ministry of Education on how the schools could use guidance and counseling to manage the student disciplinary cases. Despite the crucial role played by guidance and counseling in maintaining positive 
discipline in schools, the findings of the study show that guidance and counseling has not been effectively used to promote learner discipline in secondary schools in Kisumu district.

Arfasa and Weldmeskel (2018) points out that there was high level of student indiscipline in south west Ethiopia. This implies that most secondary schools found in south west Ethiopia were not providing effective counseling services because most secondary schools had lack of counseling centers and program officers. Furthermore most secondary school teacher counselors were nonprofessional; due to lack of knowledge, supports and training and skills, there is limited practice of counseling services in south west Ethiopia secondary schools. Secondary schools were not making use of counseling services in curbing students' discipline.

The trend of discipline in Eritrean high schools is not different from the rest of the world, schools in the country are facing their share of indiscipline among students. PTA (Parent Teacher Association) meeting conducted in Central Region stated that there is an alarming discipline issues being experienced in the schools. Lack of proper guidance services in schools and follow up from parents, teachers and the school community were blamed for the surge of the indiscipline levels in the schools (MoE Central Region, 2017).

In Eritrean secondary schools, counseling services were commenced to cater for students with social, personal, psychological, educational and vocational problems. It was also introduced to assist teachers in managing student discipline issues (MoE, 2002). A handbook or a manual to train teachers on Guidance and Counseling for school Guidance and Counseling providers was produced in 2005 and many teachers in high school were trained as trainers to train their peers in different high schools (MoE, 2013).

Guidance and counseling in the administration and management of students discipline in Eritrea has been accepted by the various government policy documents since the country's independence in 1991. The MacroPolicy (1994) underscores the overall importance of human capital development to national development by providing lifelong and wide educational strategies which will bring about widespread learning in the Eritrean society at large. In respect to education, the Macro Policy one of the first policies to be introduced by the independent Eritrean government calls for highly disciplined students through guidance and counseling for the purpose of nation building. The same call is also reiterated by the National Education Policy of Eritrea which was produced in 2003 . The national policy makes it very clear that highly disciplined students through guidance and counseling will assist the country to develop.

Despite counseling services being part of education policy and the curriculum, the use of counseling services is still in its initial stages in many schools in Eritrea. There are some common indiscipline incidents that are reported in Eritrean schools such as assault, noise making, fighting, theft, vandalism, destruction of school property, cheating in exams, failure to do homework or refusal to take orders from teachers and administrators, unwarranted absenteeism, late coming and sneaking from class and in some rare cases smoking cigarette and drinking alcohol are reported (Hill, 2010). According to the annual report of WYSS (Warsay Yikealo Secondary School) (2017) concerns were raised about indiscipline among Eritrean high school students who converge to complete their high school studies in WYSS.

The indiscipline incidents in schools suggest that students have social, psychological and educational problems which can effectively be alleviated by adequate provision of counseling services. There is need for the students to be listened to, be understood well and then be guided out of their straining circumstances. Moreover, the indiscipline incidents in schools in the country is an indicator to the fact that there is something wrong with the way the students' are guided in most schools. These indiscipline incidents that are occurring in Eritrean high schools contributed to the need to research on assessing the counseling services offered in high schools or to the question how schools use counseling services. So this study therefore intends to assess counseling services on management of students discipline in secondary schools in Keren sub-Zone, Anseba region Eritrea.

\subsection{Problem Statement}

The Government of Eritrea considers education the cornerstone for the over-all and sustainable development of the nation. In addition, the government realizes that to achieve the goals of education, discipline is key in the formation of all-rounded students (Asfaha and Leskinen, 2017).

However; currently teachers, head teachers and parents are complaining of the indiscipline issues that are occurring in Eritrean high schools. Keren sub-zone is no exception to the reset of the country; it is experiencing its share of student indiscipline. Consistent with the grievances of the stakeholders about discipline issues, in a seminar conducted among parents and teachers in Keren sub zone list of indiscipline issues in schools were reported. In the seminar concerns were raised about group fighting, sneaking, absenteeism, bullying and lack of respect to teachers (Mesfun 2015). In another report from the Central region education branch states clearly that there are indiscipline issues among high school students in the region especially unwarranted absenteeism, fighting among students, and in some extreme cases disrespecting their teachers and smoking cigarette (Girmai, 2016).

Despite the introduction of counseling services in Eritrean high schools, the indiscipline level of students seems to persist. Therefore, it is important to ask the question, how do the secondary schools in Keren sub-zone use counseling to promote students discipline? Considering this question, this study intended to assess counseling 
services on management of students' discipline in secondary schools in Keren sub-zone, Anseba region Eritrea.

\subsection{Objectives of the Study}

The study was guided by the following objective

1. To examine the status of counseling services in secondary schools in Keren sub-zone, Anseba region, Eritrea.

\subsection{Literature Review}

In recent years, school-based counseling has become increasingly recognized by national governments across the globe as a legitimate activity to support and enhance students' journey through the compulsory years of education. Counseling is also being recognized by many states in the world in the role it plays in curbing students discipline in secondary schools around the world. The number of academic papers that are being written on school-based counseling in different countries and regions attests to the importance of counseling (Harris, 2014)

A study conducted in Australia by Sawyer et al. (2012), found out that counseling services are provided in primary and secondary schools, although the way this is organized varies across states, and may also include provision for kindergarten age children. In Australia child and adolescent mental health is a serious problem that in turn disrupts learning and teaching process. The counseling services in Australian schools seeks to improve student discipline and overall mental health of students. Cooper (2013) conducted a study on current provision of school-based counselling in across the United Kingdom and used desk research method by analyzing annual reports and minutes of meetings. The study found out that provision of school-based counselling is inconsistent in different regions of the Kingdom.

African nations are in a hurry to educate citizens in order to modernize and enhance their social, economic and political development. The concept of guidance and counseling, although relatively new in Africa has been embraced by most developing nations with enormous enthusiasm. This is because counseling is being regarded by most nations as an educational service through which efficient manpower for development can be attained (Denga, 2016).

Alutu (2015) carried out a study on the state of counseling services in secondary schools in Edo state, Nigeria and used ex-post facto design. The study also sampled teachers and teacher counselor only. The study found out that out of the ninety- six (96) public schools in Benin City, only twenty-five (25) have at least a practicing counsellor. Sophie, Ndhlovu, and Phiri (2013) carried out a study in zambia on the status of guidance and counselling services in schools. They used survey study method which was pure quantitative study. Their study found out that, out of 858 pupils who participated in the study, $628(73.2 \%)$ indicated that guidance and counselling services were available in their schools. Similarly, out of the 52 teachers who participated in the study, $39(75 \%)$ of them indicated that guidance and counselling services were available in their schools.

Wambu and Fisher (2015) explored the current status of counseling services in school in kenya. They found out that despite the government's emphasis on guidance and counseling program implementation in Kenyan schools and a rapid increase in the number of trained school counselors, lack of standardized training curriculums, ethical standards, counseling models, and role ambiguity persist.

Wako (2016) researched in Ethiopia in order to assess the status of guidance and counseling services and challenges in addressing psychosocial and academic problems in selected secondary schools at Sidama Zone, Ethiopia. The study used descriptive survey design and 258 students, 3 school counselors and 4 school administrators were participated in the study. The study revealed that majority of students are not utilizing school guidance and counseling services properly to be successful in their academic life mainly due to lack of awareness about the service in their school, weak link between school counselors and school community. Other problems for underutilization of the service are related with professional competencies of the school counselors, lack of policy direction about the service and administrative problems.

In Eritrean secondary schools, Guidance and Counseling services were commenced to cater for students with social, personal, psychological, educational and vocational problems. It was also introduced to assist teachers in managing student discipline issues (MoE, 2002). A handbook or a manual to train teachers on Guidance and Counseling for school Guidance and Counseling providers was produced in 2005 and many teachers in high school were trained as trainers to train their peers in different high schools (MoE, 2013). According to the report of UNICEF (2010), three hundred peer educators were trained to provide support to an estimated 16,487 students in solving daily life problems, and 2,292 teachers were trained to promote guidance and counseling services in secondary schools.

The above reviewed literature is so far the only known study to the researcher's knowledge conducted locally concerning the status of counseling services in Eritrean schools. There are no many studies done locally about counseling in schools. Since there are no studies conducted locally this study filled the gap by studying the status of counseling services in Keren subzone secondary schools. 


\subsection{Theoretical Framework}

This study was guided by the following theory: Social learning theory of Albert Bandura.

\section{Social learning theory}

In social learning theory, Albert Bandura (1977) acknowledges the behaviorist learning theories of classical conditioning and operant conditions that developed before his theory; however Albert Bandura came up with a distinct idea that Behavior is learned from the environment through the process of observational learning or modeling.

For any learning to take place there needs to be some kind of order in the environment. When students are disciplined they will have the opportunity to pay attention to the model, in this case the models can be the counselors, teachers, peer counselors and other school staff members. Once students pay attention to the modeled behavior by the counselor or teacher, they will be able to remember the good behavior they saw in the counselor or the teacher. It will therefore assist students in their disciplinary issues.

Bandura's (1977) social learning theory further posits that people learn from one another through observation, imitation and modeling .Students are exposed to all manner of models in the family unit, society as well as the media. Students coming from families where the parents display aggressive behavior are more likely to engage in aggressive behavior in school and participate in unlawful activities. This theory is very important in relation to the school discipline, because it argues that persistent indiscipline is an indication of problems being experienced in social institutions (the school and family), and thus schools should adopt management styles like consultations that are acceptable to all.

Turner and Shepherd (2017) explained that social learning theory seems to be relevant in terms of peer counseling. Peer counselors would have to have credibility with others in order to be influential in leading other students. In order to act as role models, according to the tenets of the theory, peers would need to be able to observe peer role models practicing good behavior. Social learning theory asserts that to be a credible role model one would need to have high status within the peer group. Therefore schools when selecting peer counselors should ensure that those with high status are specifically recruited to undertake peer counseling.

Social learning theory has a clear connection with student discipline issues in schools and this connection makes it relevant to this study. This theory can be applied in counselling where the counsellors, and peer counsellors model actual behavior of honesty, compassion and respect. Such models are aware of their power of being worthy to be emulated. According to Michael (2015) counselling departments in schools can enhance their group counseling programs by inviting successful models to the school to talk about their experiences. The expectation is that members of the group counseling students can imitate the role model and influence other students in the school. School administrators, teachers and other staff members can also enhance behavior change through modelling of good behavior.

Lyon (2015) also expresses that it is essential to teach and model desired behaviors, and the benefits of positive reinforcement are well established. Teachers need first to notice the desired behavior and then praise the child. Students learn best from what they see and they model their behavior on that of their teachers or parents. Therefore the school community and parents have a great influence on how a student behaves. If teachers and parents become good models to the students the indiscipline issues that are prevalent in schools will reduce significantly.

\subsection{Research Methodology}

The study used convergent parallel mixed method research design. Questionnaires and interview guide were used to collect data. Questionnaire was given to teachers and students whereas interview guide was administered to head teachers and teacher counselors. A sample of 306 students, 20 teachers, 5 head masters, 5 teacher counselors were used for this study. Systematic sampling, simple random and purposive sampling were used to select schools and the participants. The validity and reliability of the instruments was guaranteed by piloting and Cronbach Alpha technique. Data gathered through questionnaires was processed using descriptive statistical techniques involving frequencies, percentages and means. Results were then presented using tables, pie charts and bar graphs. Data gathered through interview guides was analyzed and presented using quotes, themes and narrative descriptions.

\subsection{Results and Discussion}

Status of Counselling Services in Secondary Schools in Keren Sub-Zone

In the following table student were asked whether their school had counselling service, at the same time they were asked if they have ever attended counselling and if they did, how often they attended. 
Table 1 Availability of Counselling services in School, students' Attendance of Counselling services and Frequency of Counselling Attendance by Students.

\section{Availability of Counselling Services in Schools}

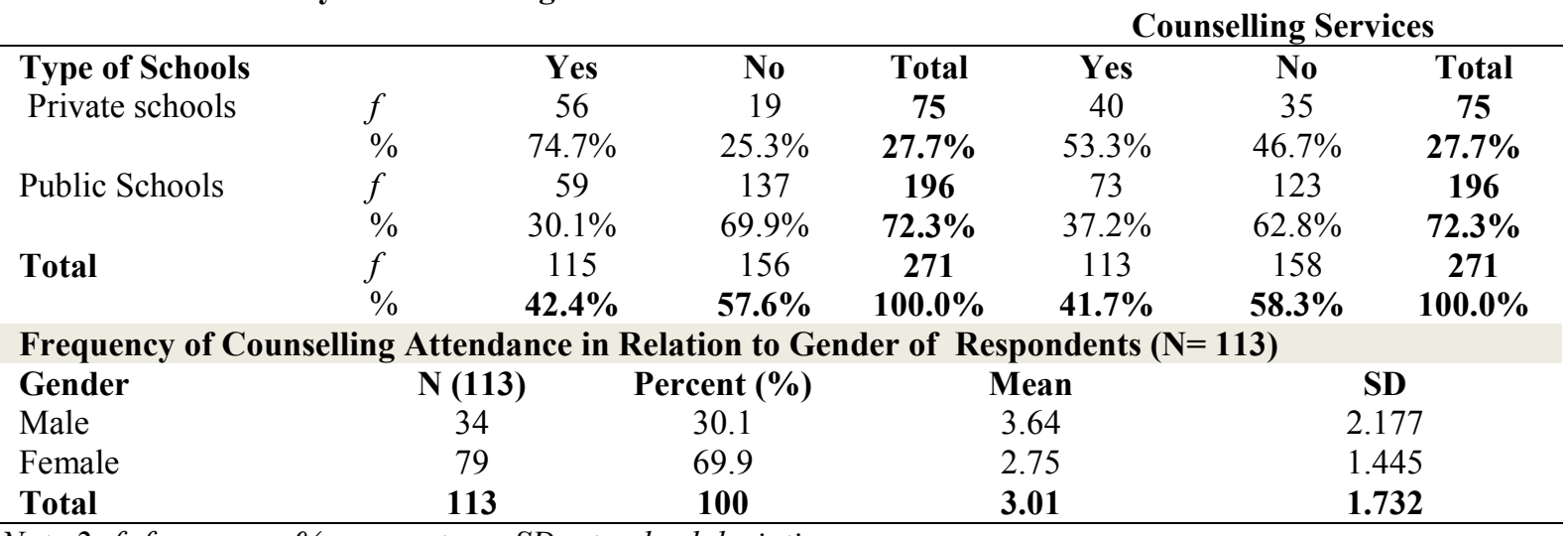

Note 2: $f:$ frequency, \%: percentage, SD: standard deviation

As shown in the above Table 1 , most $(74.7 \%)$ of the private students were aware their schools had counselling services. However, majority, $(69.9 \%)$ of the public school students were not aware that their schools had counselling services. Overall majority, $57.6 \%$ of students were not aware their schools had counselling services. Regarding attendance of counselling services by the students, most, $(53.3 \%)$, private school students had attended the counselling services while only $37.2 \%$ of the public students attended the counselling services. In relation to gender and counselling services attendance, $69.9 \%$ of those who had attended the counselling services were female students. However, of those who had attended the counselling services, male students had higher rate of attendance than their female counterparts.

The results are clear indication that counselling services are not to the level of the expected standards. This result corresponds to the findings of Wako (2016) that states the majority of students in Ethiopian schools did not attend school counselling services properly hence it affects their behaviour and discipline in school. Similarly Sophie, Ndhlovu and Phiri (2013) in their study in Zambia found out that $72 \%$ of students in private schools indicated that their school had a counselling service, whereas $53 \%$ of public students indicated that their school has counselling services.

Findings from the qualitative analysis as reported by head teachers from public schools showed that there are no formal offices for counselling services, however counselling services are provided through student affairs office. Although, there were higher awareness and attendance level of counselling services among private students, the school counsellors from the private schools reported that there were inadequate resources in running the counselling services effectively. Therefore, the results of the current study showed that the status of counselling service in Keren subzone secondary schools was very low and lacked the basic facilities.

Table 2 Availability of Counselling Services in schools According to Teachers

\begin{tabular}{lll}
\hline & Frequency & Percentage \\
\hline Yes & 4 & $25 \%$ \\
No & 12 & $75 \%$ \\
Total & 16 & $100 \%$ \\
\hline
\end{tabular}

According to teachers, most, $(75.0 \%)$, revealed that their schools did not have counselling services. Only $25 \%$ of the respondent teachers said their school had counselling services. This finding correlates with the students' response that majority, $(57.6 \%)$, had reported their respective schools had no counselling service. The results in Table 2 are clear indication that counseling services are not well established in schools in Keren subzone. The current study is similar with Arfasa and Weldmeskel, (2018) finding that revealed almost all secondary schools in South West Ethiopia did not have guidance and counseling services. Among selected 18 secondary schools only 8 secondary schools have counseling centers. Among secondary schools having counseling center, only four secondary schools have psychology background personnel while in remaining schools counseling officers were from different fields of study. Also Comfort (2013) reported that on evaluation of the status of guidance services in secondary schools in rivers state, Nigeria show that, out of the secondary schools in the state the majority did not have a counseling center. It is very clear that from the findings of the current study majority of schools in Keren subzone did not have counseling services and those that have it did not have trained counselors and proper offices for counseling purposes.

Status of Counselling Services According to Students and teachers respondents

The following table shows student responses on current status of counselling services in schools in Keren subzone. 
Table 3 status of counselling services in schools students' response

\begin{tabular}{llccccc}
\hline & & Strongly agree & Agree & Undecided & Disagree & $\begin{array}{c}\text { Strongly } \\
\text { disagree }\end{array}$ \\
\hline Our school has counselling & $f$ & 46 & 38 & 10 & 82 & 95 \\
office & $\%$ & 17 & 14 & 3.7 & 30.3 & 35.1 \\
Our school has counselling & $f$ & 47 & 90 & 25 & 31 & 78 \\
services & $\%$ & 17.3 & 33.2 & 9.2 & 11.4 & 28.8 \\
Counselling is part of & $f$ & 94 & 64 & 20 & 33 & 60 \\
curriculum & $\%$ & 34.7 & 23.6 & 7.4 & 12.2 & 22.1 \\
Our school has peer counselling & $f$ & 32 & 64 & 42 & 65 & 68 \\
programs & $\%$ & 11.8 & 23.6 & 15.5 & 24 & 25.1 \\
Our school has group & $f$ & 13 & 78 & 47 & 64 & 69 \\
counselling programs & $\%$ & 4.8 & 28.8 & 17.3 & 23.6 & 25.5 \\
Our school has individual & $f$ & 31 & 53 & 40 & 45 & 102 \\
counselling sessions for students & $\%$ & 11.4 & 19.6 & 14.8 & 16.6 & 37.6 \\
Our school has enough & $f$ & 40 & 54 & 40 & 48 & 89 \\
counselling resources & $\%$ & 14.8 & 19.9 & 14.8 & 17.7 & 32.8 \\
\hline
\end{tabular}

Note 3: f: frequency, $\%$ : percentage

In relations to status of counselling Table 3 showed that $35.1 \%$ of the respondents strongly disagreed that their school had counselling office. In a similar way $28.8 \%$ of the respondents strongly disagreed that counselling service were available. However $17.3 \%$ and $33.2 \%$ of the respondents strongly agreed and agreed respectively that their school had counselling services. Therefore the result of the current study confirms that the availability of counselling services is very low in Keren subzone secondary schools. Head teacher 1 confirmed the results of students by saying, "I can grade the status of counselling in my school as fair, though we don't have formal office and a trained counsellor, our school is trying its best to apply the services to manage students' discipline."

The findings show that most $(34.7 \%)$ of the respondents strongly agreed that counselling is part of the curriculum which was also reflected by $37.5 \%$ of the teachers' respondents. The majority $(35.1 \%)$ of the respondents strongly disagreed the school has counselling office which also appears in school has individual counselling sessions for students $(37.6 \%)$ and there is enough counselling resources $32.8 \%$. this was replicated by the majority $(37.5 \%)$ of teachers respondents as well.

The findings of the currents study show that despite counselling being part of the curriculum most schools do not have counselling offices, peer and group counselling, individual counselling services. The schools do not have sufficient resources to effect counselling in their schools. In turn the absence of crucial counselling services materials and programs affects students discipline in schools. This results are no different from the findings of Alutu (2015) who carried out a study in the state of counselling services in Edo state, Nigeria and found out that out of 96 school in Benin city, only 25 schools have a practicing counsellor even though most were untrained. Counselling services are faced with many difficulties such as lack of proper funding, lack of basic counselling material, trained counsellors and proper offices. In addition Wako (2016) in a study conducted in Ethiopia found out that schools lacked basic counselling facilities such as proper office and resources. The findings also indicated that group counselling and peer counselling were almost non-existent.

Table 4 status of counselling services in schools teacher response

\begin{tabular}{|c|c|c|c|c|c|c|}
\hline & & Strongly agree & Agree & Undecided & Disagree & Strongly disagree \\
\hline Our school has counselling & $f$ & 2 & 2 & 4 & 3 & 5 \\
\hline office & $\%$ & 12.5 & 12.5 & 25.0 & 18.8 & 31.3 \\
\hline Our school has counselling & $f$ & 2 & 3 & 4 & 5 & 2 \\
\hline services & $\%$ & 12.5 & 18.8 & 25.0 & 31.3 & 12.5 \\
\hline Counselling is part of & $f$ & 6 & 4 & 4 & 0 & 2 \\
\hline curriculum & $\%$ & 37.5 & 25.0 & 25.0 & 0 & 12.5 \\
\hline Our school has peer counselling & $f$ & 0 & 2 & 5 & 4 & 5 \\
\hline programs & $\%$ & 0 & 12.5 & 31.3 & 25.0 & 31.3 \\
\hline Our school has group & $f$ & 0 & 3 & 3 & 6 & 4 \\
\hline counselling programs & $\%$ & 0 & 18.8 & 18.8 & 37.5 & 25.0 \\
\hline Our school has individual & $f$ & 2 & 2 & 4 & 7 & 1 \\
\hline counselling sessions for students & $\%$ & 12.5 & 12.5 & 25.0 & 43.8 & 6.3 \\
\hline Fully equipped counselling & $f$ & 0 & 2 & 4 & 4 & 6 \\
\hline room/office is available & $\%$ & 0 & 12.5 & 25.0 & 25.0 & 37.5 \\
\hline There is enough counselling & $f$ & 2 & 2 & 2 & 6 & 4 \\
\hline resources & $\%$ & 12.5 & 12.5 & 12.5 & 37.5 & 25.0 \\
\hline
\end{tabular}

Note 4: f: frequency, \%: percentage 
As indicated in Table 4, $31.3 \%$ of teachers respondents strongly disagree that their school has counselling office, while $25.0 \%$ were undecided whether their school has counselling office. Only small percent of teacher respondents that is $12.5 \%$ strongly agree their school has counselling services, whereas most of them that is $25 \%$ were undecided and $31.3 \%$ disagreed their school has counselling services. From the qualitative analysis teacher counsellor 2 confirms the response of teachers by saying, "If I am to evaluate the status of counselling services in my school, I would say it is less than the expected standard. Lack of formal office and huge class size of students makes counselling very difficult task."

A high number of the respondents $37.5 \%$ and $25 \%$ strongly agreed and agreed respectively that counselling was part of curriculum. Despite counselling being part of school curriculum, $31.3 \%$ respondents strongly disagreed that their school has peer counselling and 37.5\% disagreed there was group counselling service. In a similar way $43.8 \%$ disagreed that there was individual counselling sessions. And $25 \%$ were undecided whether there was individual counselling session in their school. A big number, 37.5\% of respondents strongly disagreed that there was fully equipped counselling room. In a similar way $37.5 \%$ disagreed there was enough counselling resources. It is noteworthy that there was no single respondent who strongly agreed that their school had fully equipped counselling room. Therefore the result shows that the states of counselling in secondary schools in keren subzone is very poor. Since the service is not fully functioning it has very low effect on student discipline. Such results are reflected in the findings of Salgong, Ngumi and Chege (2016) In relation to the status of guidance and counselling in kenyan schools, their findings showed that $33.3 \%$ of the respondents strongly disagreed that guidance and counselling was available in the schools. In a similar vein, $60 \%$ of the respondents strongly disagreed that counselling facilities are available in secondary schools. From the foregoing, it is evident that counselling services lack the required resources in enhancing student discipline in school. Specifically, counselling facilities, individual counselling rooms and fully equipped office need to be looked into critically.

\section{Conclusion}

The findings of the study revealed that the current status of counselling services in Keren secondary schools was below the expected standards. According to the findings of the current study the status of counselling services was poor in Keren secondary schools. Private schools had a better attendance level compared to public schools in terms of attending counselling services. In over all, female students attended counselling services more than male students. The study revealed that the status of counselling service in Keren secondary schools was poor. Majority of students, $57.6 \%$ and $75 \%$ of the teachers reported that their schools did not have counselling service. However, there was a difference between private and public school students on awareness about the availability of counselling services. In private schools $74.7 \%$ of the students revealed that they were aware of the presence of counselling service, whereas only $30.1 \%$ of public students were aware about the availability of counselling service. In terms of attending counseling services, majority, $58.3 \%$ of the students did not attend counseling services. Although, there were higher awareness and attendance level of counselling services among private students, the school counsellors from the private schools reported that there were inadequate resources in running the counselling services effectively.

The finding from the qualitative data revealed that head teachers and teacher counselors evaluated the status of counseling services in Keren secondary schools as poor and fair. They reported that schools did not have counseling offices and properly trained counselors for the purpose of counselling.

\section{Recommendations}

The ministry of education should revise the curriculum for secondary school education so that to incorporate a well-functioning counseling service. From the findings of the current study, it came out clearly that counselling services though present in the national curriculum it is not practiced by majority of the schools and the little that is available is also practiced by unqualified and untrained teachers who head other offices as their prime responsibility. The ministry of education should ensure that counselling services are provided by qualified and trained counselors so that it assist in managing students' discipline.

In addition, the ministry of education should come out with clear guide and policy on how to implement counseling services in schools. The current study made it very clear that no school has a separate room for counseling service, which makes it very difficult to teacher counselors to provide counseling services to students. The Keren sub-zone quality assurance office need to ensure that set policies are dully followed to standard in secondary schools in Keren sub-zone.

School head teachers being the highest managers in schools should create a conducive atmosphere for counselling process to happen so as to assist students in managing discipline. From the findings of the current study it is evident that the current status of counseling services in Keren secondary schools is in its lowest level, due to that reason students are not using it. Students should be encouraged and motivated by their teachers to attend counselling services in order to assist students in managing their discipline in schools. The environment in secondary schools should allow for free and open interaction between students, teachers and teacher counselors. 
The finding of the study indicated that students feel shy to attend counselling service and counsellors were not friendly.

Finally, it is hoped that the findings of this research study will contribute to scientific knowledge and to existing literature on the assessment of counselling services on management of students' discipline in secondary schools in Keren sub-zone, Anseba Region, Eritrea and in general.

\section{References}

Arfasa, A.J. \& Weldmeskel, F.M. (2018). The State of Guidance and Counseling Services in Southwest Ethiopia Secondary Schools. International Journal of Scientific and research publications, 8(7), (357-362).

Asfaha, M.Y. \& Leskinen, M. (2017). Educational reflections from Eritrean learning for all. Finland: University of Jyvaskyla Press.

Ajowi, J.O. \& Simatwa, E.M.W. (2016). The role of guidance and counseling in promoting student discipline in secondary schools in Kenya: A case study of Kisumu district. International Journal of science and Research, $4(12),(13-32)$.

Alutu, N.A. (2015). The state of guidance services in secondary schools in Edo state, Nigeria. The Nigerian Journal of Guidance Counselling, 10(1), (114-125).

Bandura, A. (1977). Social Learning Theory. Englewood Cliffs, NJ: Prentice Hall.

Cooper, M. (2013). Counselling in UK secondary schools: A comprehensive review of audit and evaluation studies. Counselling and Psychotherapy Research, 9(3), (137-150).

Girmai, G. (2016). Workshop Focusing on Outcome of Education and Student Discipline. Ministry of Education.

Harris, B. (2014). Locating School Counseling in the Asian-Pacific Region in a Global Context. Brief Reflections on a Scoping Review of School Counseling Internationally. Journal of Asia-Pacific Counseling, 6(23), (1$8)$.

Hassain, S. \& Faisal, R.A (2016). Guidance and counseling in schools of Bangladish. International Journal of science and Research, 2(10), (132-138).

Hill, J. (2010). What Challenges does Life Present to Teachers in War-torn Nations. New Castle: Oxford University Press.

Kimotho, F.W., Njoka, J.N. \& Gitumu, M.W. (2017) Impact of Guidance and Counseling Services on Students' Discipline: A Case of Public Secondary Schools in Eastern Kenya. Kenya Journal of Educational Planning, Economics \& Management, 11 (1), (35-46).

Louis, B.J. (2018). The causes of a lack of discipline among secondary school learners. Mediterranean Journal of Social Sciences, 9(1), (35-46).

Luti-Mallei, R.M. \& Komo, D.G. (2016). The Influence of Categorization of Schools on the discipline of boys and girls in Public Secondary Schools in Machakos Sub-County, Kenya. European Journal of Education Studies, 2(8), (74-83).

Lyon, C. (2015). Proposal to Abolish the Parental Rights to Reasonably Chastise their Child under the UK Law. Institute of Public Research, 19(13), (275-279).

MoE (2002). The Concept Paper for a Rapid Transformation of the Eritrean Education system. Government of Eritrea.

MoE (2013). Education Sector Development Plan 2013-2017. Government of Eritrea.

MoE Central Region, (2017). Spare the rod and educate the child. Asmara: Shabait.

Mesfun, A. (2015, October 17). Parents and Teachers Committee in Keren Sub-Zone reiterate Readiness to Step up Efforts to Curb Discipline of Students. Eritrean Profile, P. 2.

Michael, P. (2015). Social Learning Theory and Its Importance to Social Work. Social work license map.

Salgong, V.K., Ngumi, O. \& Chege, K. (2016). The role of guidance and counselling in enhancing studet discipline in secondary schools in Kiobatek District. Journal of education and Pracitce, 7(3), 142-151.

Sawyer, M. G., Arney, F. M., Baghurst, P. A., Clark, J. J., Graetz, B.W., Kosky, R. J. Nurcombe, B., Patton, G. C., Prior, M. R., Raphael, B., Rey, J. M., Whaites R. C., \& Zubrick R. (2012). The mental health of young people in Australia: key findings from the child and adolescent component of the national survey of mental health and well-being. Australian and New Zealand Journal of Psychiatry, 35(34-37), (806-814).

Schaefer, k. \& Ginsberg, A.P (2015). The effectiveness of the warning signs program in educating youth about violence prevention: A study with urban high school students. Professional school counseling, 7(1), (1-11).

Sophie, K., Ndhlovu, S.M., \& Phiri, T.J. (2013). Impact of guidance and counselling services on high school pupils in Zambia. The Nigerian Journal of Guidance Counselling, 10(1), (114-125).

Turner, G. \& Shepherd, J. (2017). A method in search of a theory: peer education and health promotion. Health Education Research, 14 (2), (235-247).

UNICEF (2010). UNICEF Annual Report for Eritrea. United Nations Publication.

Vann, K. (2013). Importance of guidance and counseling in schools. New Delhi: RSS Publishers.

Wako, A. (2016). The Status Guidance and Counseling Services in Ethiopian Secondary Schools in Addressing 
the Psychosocial and Academic Needs of Secondary School Students: The Case of Sidama Zone. Journal of Humanities and Social Science, 21(2), (27-35).

Wambu, G.W. \& Fisher, T.A. (2015). School Guidance and Counseling in Kenya: Historical Development, Current Status, and Future Prospects. Journal of Education and Practice, 6(11), (93-102).

WYSS (2017). Report of Guidance and Counseling 2012, Sawa. Sawa: WYSS. 